\title{
LEAGUE PUBLICITY: CAUSE OR EFFECT OF LEAGUE FAILURE?
}

\section{By PITMAN B. POTTER}

\begin{abstract}
Dr. Potter has been Professor of International Organization at the Graduate Institute of International Studies, Geneva, since 1930. Previously he was for twelve years at the University of Wisconsin. He is a graduate of Harvard, and received the Ph.D. degree from the same institution in 1918. He has been intimately acquainted with work of the League of Nations and in 1935 was legal adviser to the Ethiopian Government and a member of the Italo-Ethiopian Arbitration Commission. The Quarterly is glad to present Dr. Potter's analysis of League publicity as illuminating one of the central problems which must be faced by any international organization, now or in the future.
\end{abstract}

$\mathrm{I}_{\mathrm{n}}$ this study ${ }^{1}$ of the publicity work of the League of Nations, a seemingly logical theory of the League and its publicity work will first be stated. This will be followed by the theory professed by the League itself, then a description of the actual organization and conduct of its publicity work. Finally the League theory will be compared with actual practice, and the hypothesis with this practice likewise.

\section{HYPOTHESIS}

Juridically the League consists of a system of rights and obligations set up by the Member States among themselves and various agencies. The League seeks various objectives which are stated in the Covenant or have been developed since adoption of

1 The author has enjoyed the tremendous benefit of consultations with numerous persons in the Secretariat of the League, including particularly Dr. Benjamin Gerig, Member of the Information Section and sometime Acting Director thereof, Mr. Adrian Pelt, Director of the Information Section, and Mr. Arthur Sweetser, formerly Member of the Information Section and sometime Acting Director thereof, and with Dr. William E. Rappard, formerly Director of the Mandates Section, now member of the Permanent Mandates Commission and other League organs, Professor and Rector of the University of Geneva, and coDirector of the Graduate Institute of International Studies, Geneva. None of these gentlemen can, however, be held responsible for either statements of fact or of the interpretations which follow. 
the Covenant. At certain points this involves action by League organs directly upon citizens of Member States.

Hence the publicity work of the League might, a priori, be carried on by Member Governments or by any League organ. If that work were to be systematically planned and carried out, it should be outlined by the representative bodies (as the Assembly and special conferences) and carried into execution by the administrative organs (as the Secretariat and, in certain aspects, the Council). But if the League proves to resemble any other governmental organization much publicity would be carried on without systematic planning, and some would be carried on by all of the organs named, especially in case of a mixture of functions in those organs.

The publicity work in question would consist of all types of representations making known League structure and activity. Presence of promotional purposes on behalf of the League would add another, and, strictly speaking, irrelevant element. These representations might be true or false, although false representations would require special efforts (consistency, protection against disproof, etc.) for their support. In so far as these representations were true they could all be analyzed into the form of factual statement. Even explanations, interpretations, and argumentation, designed to have promotional or persuasive effect, must take the form of representations of fact.

The representations might be distributed directly to private individuals, or to organized groups of such individuals, in one or more countries, Members of the League or not; to national governments, in Member States or non-Member States, to private international organizations and to public international organizations -the League's "public" is highly complex in character.

It would seem that such dissemination of information should logically be complete and impartial with respect to both material and recipients. All data should be available to everybody, leaving questions of choice to the recipients, although the League might call attention to specially important materials. If any selection had 
to be made the standard should be relevancy to the present time: not political but chronological or other external standards of selection should rule. Data should be offered to all persons and Governments, irrespective of obstacles, either natural or political, i.e., even obstacles erected by Governments themselves.

\section{LEAGUE'S THEORY OF PUBLICITY}

The theory of publicity which the League has professed may be summarized briefly. It has been formulated chiefly by persons engaged in that work, more specifically by the League Secretariat and the Information Section thereof. Not much attention has been given to the subject by other League officials or delegates.

Publicity work is undertaken by the League, according to this theory, ${ }^{2}$ in order to influence public opinion, because "the progress of the League of Nations depends on public opinion." As yet, however, international questions cannot be dealt with on a basis of international opinion. The influence of opinion on international action consists chiefly of the influence of national opinion on its own Government. It may be very difficult to convince national opinion in any one state of the wisdom of certain international action; the position of the national Government will be determined in part by this fact; in any one country the League is represented by the Government in such situations. No League policy exists on any item until agreement is reached. Even if a Government agrees, the League as such has no authority to urge upon the opposition in that country the policy adopted. The League has no organic existence apart from its Members. As an organization it does attempt to persuade Governments and public opinion but it respects the independence of the States and acts diplomatically for fear of failure. The Secretariat is the servant of all Members equally and cannot express particular policies; it

2 Taken chiefly from Chapter XIV of Ten Years of World Cooperation, written and published by the Secretariat of the League in 1930, but still unrevised. This work cannot be regarded as an official document, nor were the authors, in view of their official position, free to write as might a private student; nevertheless the text may safely be regarded as an accurate statement of what the Secretariat professed to believe on the matters dealt with. That which follows is a paraphrase thereof. 
can only investigate and advise impartially and must not take sides. League publicity means public discussion and documentary publications, and above all close relations with the press. The League can have no newspaper of its own to print and interpret news but must rely on the ordinary newspapers. It may also publish books and pamphlets and photographic materials, make contact with unofficial organizations, make use of the radio, etc. But it may not engage in propaganda. It may provide facilities for students, teachers, and newspaper workers, including opportunities for interviews, and may help to explain events to them. It may maintain field offices, sell its publications, present them to libraries and individuals, and take part in expositions everywhere.

\section{ORGANIZATION AND CONDUCT \\ OF LEAGUE PUBLICITY}

Publicity is undertaken by the League through a greater number and variety of agencies than is ordinarily realized. Thus we cannot ignore publicity work by private organizations in Member States and in the international sphere, especially as a certain amount of cooperation with national Governments and League agencies exists in this connection. Certainly publicity work by Member State Governments cannot be overlooked, and this ranges all the way from public declarations by heads of state to administrative measures by departments of Government; again League cooperation always exists here in varying degree.

In the League organization the representative bodies such as the Assembly, Council and conferences come first. The League as a collectivity of its Members utilizes these bodies for publicity purposes by having them meet in public. Individual delegates support this by making declarations on League action or the policies of their Governments.

In the Secretariat we find most of the agencies specifically intrusted with League publicity.

It is impracticable to describe fully the publicity work of the Information Section and other units of the Secretariat. Even listing 
them fully is difficult. The Information Section communicates to press and public such information as it deems advisable. It prepares thousands of articles, pamphlets, and books on the League and the subject matters dealt with by the League, and photographic materials of all kinds (negatives, prints, cinema films, lantern slides, and radio-broadcast photos). It operates the League's weekly radio broadcast. It manages the distribution of tickets to the press for Assembly, Council, and other meetings; distribution of tickets to the public is, for reasons of safety, ${ }^{3}$ handled by Internal Services. It provides extensive and varied facilities for the press, including reports-some distributed by airmail and radio-telegram-of League activities and meetings whether attended by the press or not. Various studies and discussions have been instituted, and one full-dress International Press Conference (1927), on the problem of the press and international relations. Contact is maintained with thousands of individuals and organizations in all countries through their representatives in Geneva and visits to these countries. A similar end is served by field offices maintained in ten countries. Lectures are provided for students visiting Geneva, also phonographic lectures. Temporary collaboratorships have been instituted whereby students and teachers may work in the Secretariat. Inquiries by letter are answered by the thousands. Libraries and educational institutions everywhere are provided with materials. Exhibits are provided for world expositions, and space in the League buildings in Geneva is similarly utilized, not to mention facilities provided for tourists to visit these buildings. ${ }^{*}$

The most novel development of the League's publicity work is its radio-broadcasting activity. The League has facilities for such

\footnotetext{
${ }^{8}$ Required by the local police; the demonstrations against the League buildings at the time of the Sacco-Vanzetti trial, resulting in some 10,000 francs damage, together with various incidents in Council and Assembly meetings-blows, a suicide, demonstrations and threats against Fascist and Communist delegates-suffice to show the need for such precautions.

4 This matter of personal visits to the League buildings should not be underestimated; a tourist refused admittance to a League mecting or denied facilities to inspect the buildings is an enemy for life-even though the denial be based on good grounds ("Visites seulement samedi et dimanche").
} 
activity just outside of Geneva and uses them for transmitting official communications to Member States and, for fifteen minutes each Sunday night, broadcasting talks on the League, with multiple translation, preceded and followed by music of different nations. These are prepared and transmitted by the Information Section; hundreds of communications are received weekly in response and comment. In spite of its undeveloped state, League broadcasting is potentially a peculiarly powerful instrument.

The publicity activities of the other divisions of the Secretariat may be listed more briefly. The Document Service provides the thousands of League documents, some of them books in many volumes, which are distributed by the Information Section and the Distribution Service, sold by League agents in all countries, and placed in the Library. The Library itself serves the hundreds of students who come to Geneva and maintains an information service answering thousands of inquiries by correspondence; its materials cover all aspects of international relations and its bibliographical publications do the same; a gift of $\$ 2,000,000$ by $\mathrm{Mr}$. J. D. Rockefeller, Jr., has made it possible to expand greatly the Library's plant and services. Finally the Legal Section provides from its treaty registry the material for the Treaty Series while the International Bureaus Section relays to hundreds of private international organizations all kinds of League information.

The work of the Intellectual Cooperation Organization relates to a variety of matters, but also includes education in the aims and activity of the League. The Section in the Secretariat participates in this work, of course, and finally a number of National Committees in Member and non-Member States do likewise, which brings us back to the point of departure in this survey.

\footnotetext{
5 No mention las been made in the text of publicity work concerning the League by others than League agencies, Members, or their citizens. Such work is, however, carried on and should be briefly noted. Such is publicity on behalf of the League by non-Member States-speeches by the President of the United States, e.g. - and private organizations therein, such as the League of Nations societies. It might not be out of place to mention the American Committee which functions in Geneva each summer to provide visitors, American and other, with information and assistance.
} 


\section{CORRECTION OF THEORIES}

The theory professed by the League seems incomplete and contradictory. Little attention is given to publicity work by Member Governments, including delegates to League meetings and Permanent Delegates in Geneva. With respect to objectives and procedure of the League, the League theory seems unduly narrow. It cites peace and mutual aid as general objectives, but says little about minorities, sanctions, revision, or some other special League activities. At no point is this task of League publicity conceived as a whole or planned systematically. The Information Section was deliberately created and its work given much thought; its work is planned carefully, year by year, in point of method, though peculiarly susceptible to the interruption of unexpected events; but this is the most that can be said.

The League's theory diverges most widely from logical theory at the point of contact with the public. The object of its representations is visualized solely as that of influencing public opinion or popular feeling, which is given a very low rating. The theory at this point seems to have been written with a cynicism and a hyperrealism worthy of an economic determinist or a disappointed lover. It disregards almost entirely the object of providing materials for scientific study, apart from current political life. Furthermore it is admitted that the League cannot or should not, even in case of unanimous League policy, offer representations in any state where there is opposition, the very situation where such action might seem most necessary. There is a disingenuous preference for calling the League activity under consideration "information" rather than "publicity" work. League radio broadcasts, likewise, are professedly made colorless by elimination of all value judgments. And the attention given to the problem of error and misrepresentation, scientific representation and propaganda, is inadequate.

Absence of any comprehensive and permanent plan of League publicity work has led to opportunism, and contradictions have 
appeared within the theory itself and between the theory and the practice. Thus the theory that the League must not publish material offensive to Member States harmonizes ill with its publication of health and social information most invidious to these States. The contention that the League "cannot engage in propaganda" is contradicted in practice and by the admission of propaganda for general international cooperation. Again it is said at one moment that the League can have no newspaper of its own and at another that it has one. ${ }^{6}$ Every effort, it is said, must be made to be complete and impartial, but at the same time it is admitted that nothing must be said to give offense to any Member Government and it is not realized that indirectly this means being positively partial.

The reasons for the divergence between League theory and the logical hypothesis, as they would be given by a League spokesman, may be stated briefly. Haste in organizing the League in 1919-20 made planning impossible, and the historical novelty of the League makes its publicity work a precarious adventure. The States had accepted the League in I9I9 reluctantly and they were essentially opposed to its becoming very strong; they therefore hold back the Secretariat in its publicity work. This is particularly true of the Great Powers, their foreign office and diplomatic officials, who are jealous of this new super-national organization; certain small states, likewise, fearful of domination by the Great Powers in the League, take the same position, though if really given protection by the League they would take a different position. The States feel compelled to permit dissemination of factual information but do not desire promotion or propaganda even for League principles. Although they cannot avoid this respecting the main League ideals-peace and cooperation-they hamper it respecting details of League action (minority protection, revision) where the effects may displease them individually. Definition of League policy, except by quotation of Assembly or Council texts, is a hazardous task, not confided clearly to any official. The In-

Compare Ten Years, p. 403, top, with pp. 410-11. 
formation Section was smashed by the Members in 1933, under pretext of economy, just because of such political and personal considerations, and converted into a mere press bureau of half its previous size. ${ }^{7}$ Unrestrained publicity or open crusading, even preaching 100 per cent League principle, would actually defeat the purpose of promoting League success today.

Much may be said for this apologia. The hypothesis previously stated assumed that the intention expressed by the States in 1919 to create and operate a League of Nations was genuine and strong; that assumption is open to question, and any sound theory would take possible insincerities at this point into account. Not only was no publicity or promotion provided by the States, but they have in fact been very suspicious of it from the beginning. The first Secretary-General, Sir Eric Drummond, and especially the first Director of the Information Section, M. Pierre Comert, were in favor of reasonable publicity and even promotion. Their task required great skill. The work has been carried on according to treaty stipulations, cited whenever appropriate, and though relatively extra-legal in character has been harmonized with existing law as far as possible. Certainly the work has been carried on with the success of the League constantly in view.

Certain critical comments must, however, be made. League officials cherish an exaggerated idea of the novelty of the League in history. Moreover the League's own theory of its publicity work is hardly more complete today than it was originally. ${ }^{8}$ Like all practising politicians, League officials are chronically negligent of theoretical considerations concerning the activity in which they are engaged. Pretending to ignore pro- or anti-League propaganda on the part of Governments or delegates or even their own propagandist activities-and these are constant and deliberate, and often appear in the very documents arguing against it-and dis-

7 ibid., pp. $401,402$.

${ }^{8}$ Recent addresses by the Secretary-General, excellent in content, if one may be permitted to express an opinion, seem to derive from other preoccupations than a fundamental change of general League theory. See addresses in Monthly Summary, July 1935 and November 1936. 
ingenuously calling them "information," only beclouds the situation. The League theory also gives altogether too much place to that irresponsible monger of fact and fancy, the daily press. Propaganda in favor of principles and procedures at least formally accepted by all Members is so different from invidious propaganda as hardly to be propaganda in any distinctive sense at all. Unanimity is not required at all points to determine League policy, nor is there any legal or logical bar to support of League policy in concurring Member States against the opposition, or even in Member States where the Government dissents. There is no violation of sovereignty in view of the original agreement to League organization and action.

The fact is that "the theory professed by the League" concerning its publicity work is a theory worked out by the Information Section and the Secretariat, not by Member States, their Governments, their delegates, or the Assembly or Council. It has, moreover, been worked out by the Secretariat in the face of the suspicion and hostility of the Member States as a theory of what it may do in view of that hostility. If it had been a theory formulated by Member States intent upon promoting the League for all it was worth, and defining what they could do in the way of publicity and propaganda for this purpose, it would have been a very different thing. The defects and contradictions were, to some degree at least, forced into the Secretariat's theory by the Member Governments.

In strict theory the Secretariat officials are administrative agents, authorized simply to carry out legal stipulations already approved by the Member States. Their publicity must follow such stipulations, or, in absence of explicit prescription, the implications of existing stipulations. Leadership they may not exercise, or any policy-determining power. At the same time they could logically be expected to stand firm for observance of existing law, even if this takes on the appearance of political leadership against disloyalty on the part of Members. From this ambiguity have arisen the difficulties of the Secretariat Information Section. 


\section{VALUE OF LEAGUE THEORY AND PRACTICE}

The basic question is the degree of prudence necessary, and there can be no sure answer. Does the Secretariat exaggerate the danger of Member State interference in the form of vague political pressure and authoritative and financial control? In a sense this is the kernel of the whole problem. Those who do not see or feel that opposition will advocate going as far as possible, not anticipating dangers in advance, and retreating only if necessary. ${ }^{\circ}$ The Secretariat officials, remembering 1933 and countless checks administered by the enemy, will advise against this. There is no a priori reason why the Secretariat should be more diplomatically inclined than the diplomats. If it has been intimidated, led into espousing seemingly unsound theory, and into practising subterfuge and concealment, there must be some special reason, unless, indeed, the very solicitude for its brain-child makes it overtimid.

That reason is in part, of course, that the delegates and Governments represent vigorous national communities or at least powerful governmental organizations, while they, the Secretariat officials, feel that they represent nothing but a weak international organization, a vague international community, or a still vaguer humanity-at-large. This, however, is of the essence of the problem, given in advance and assumed by all.

It is really a question of strategy-is it better to seek victory by candid frontal attack or by discretion, conciliation, indirection. If the enemy is sufficiently alert and determined, then neither method may succeed much better than the other. The facts seem to indiçate that this has been the case here, unless it is believed that a frank show-down would have rallied sufficient popular support and small-nation support to defeat the opposition.

The consequences on Secretariat publicity work of professing a certain theory were inevitable. They were mitigated by the fact

\footnotetext{
${ }^{\circ}$ They will point to the success reaped by Albert Thomas, as Director of the International Labor Office, in employing the opposite method. It should, however, be pointed out that Thomas was operating in what was, after all, a less delicate field. It might also be added that Drummond and Comert were actually more sympathetic toward general publicity than was Thomas and that to this day the publicity service of the Labor Office is less effective than that of the League.
} 
that the theory actually held by Secretariat officials, and acted on by them, was somewhat different from that which they professed for protective purposes. In the result the work done has seemed very extensive, very detailed and specific, very solid in quality, as lively or vivid as could be expected, solicitous in attitude and more impartial and honest than many delegates, "revising" their speeches in the record before final publication. All kinds of opportunities have been exploited by the use of all kinds of facilities. All kinds of material have been sent out in all sorts of ways to all sorts of people. The press service of the League is almost certainly superior to that of any foreign office in the world if not of any Government as a whole. One quality only may have been lacking, that of moral courage.

One curious development of the attitude of reducing pressure in favor of international cooperation, and trusting to the national governments to press toward that end with sufficient zeal, is seen in the opposition to dealing with private international organizations. ${ }^{10}$ Representations from such organizations are sometimes received and the organizations given information, but the general attitude is that just described. If the League desired to encourage public opinion in support of international cooperation nothing could be more logical than cooperation just here; actually such organizations were and still are regarded with suspicion and hostility. Granted that the cranks and agitators in some of these organizations are bothersome, this attitude constitutes a sort of psychological fatuousness. And it is not enough to say that such pressure-action should be taken in individual states vis-à-vis individual governments, for, as is indicated even in the Covenant, ${ }^{11}$ something broader than pure internationalism is needed for support of the League.

Not much need be said concerning coordination of League publicity activities. There is, in fact, only a limited amount of coordination, even within the Secretariat. But this is true in any

10 It is the Council, rather than the Secretariat, which takes this position.

11 Arts. XXIII-XXV. 
governmental system, and is next to impossible to avoid. Certainly it would be impossible and undesirable to control all of the utterances of Member Governments, individual delegates and private organizations. It is doubtful if much harm has been done by lack of complete control and unity.

The final question is whether the publicity work could have been more effective. If instead of diplomatic conciliation and political maneuvering (the methods of the two personalities who had the publicity work of the League in charge in its formative years, and who both ended up in national diplomatic service again) an attack by open propaganda had been launched, and had not been effectively checked by Member States, could it have accomplished more? Perhaps so if it had also stuck to its professed ideas concerning public opinion (popular feeling) and gone after results by the cynical methods suited thereto, instead of actually using methods assuming its rational character. The forces of nationalist greed and war were all the time conducting such a campaign on their side. By its own test the League publicity work failed ("the progress of the League of Nations depends on public opinion"); it might have succeeded if it had gone on its own theory at this point and been able to follow it. ${ }^{12}$

In point of fact the last conclusion is not obvious. The League has broken down because of failure of Great Britain and France to stand by it in general, and specifically to stand by it with force if need be for execution of collective security, and, though to a less degree, to insist upon (in one case) and permit (in another) execution of revision-all this in the face of an attack upon all

\footnotetext{
12 Except that the methods (appeals to emotions, high-pressure harangue, loudspeakers and flags and brass bands) employed by the nationalist dictator to exploit passions of hate, pride, belligerency, etc., can hardly be employed for eliciting ideas and sentiments of understanding, cooperation, and law and order. This may mean that the exploiters of hate are bound to win out in any open contest with the apostles of love, and that war will give way to peace only when people become so educated to the truth by the pressure of facts and fundamental education administered when the passions are quiet that they cannot be exploited by the war-monger-and, moreover, that peace workers can never hope to compete with the jingos in propaganda, especially in time of crisis, and must not pin their hopes on such measures.

See discussion in the Sixth Commission of the Assembly on October 8, 1936, especially the remarks of Lord Cranborne (U.K.).
} 
practice of orderly international government by three reactionary nations, Japan, Italy, and Germany, and desertion of that cause by the United States. It is doubtful whether League propaganda, had it been ever so vigorous, could have altered public opinion or popular feeling or, what is more important, governmental policy, in the anti-League countries, given the censorship, vicious attitude of the Governments, and immaturity of the peoples politically; it is almost as doubtful whether it could have had that effect in Great Britain and France, not to mention the United States.

This is no argument in favor of misrepresentation on the part of the League. It is sometimes said in League quarters that the truth is the best propaganda for the League. This is not certain with respect to certain countries. The main idea is sound: the fundamental principles of the League, including respect for law and contractual obligations, open conduct and free regulation of common affairs by voluntary agreement, pacific settlement of disputes, disarmament, collective security, adequate processes of revision, and reasonable minority protection, are the essentials of sound government everywhere, hardly open to controversy, not in need of propaganda but only needing to be stated to commend themselves to any socially-minded and intelligent human being. But it is exactly these fundamental principles, and not specific League modalities, which are under attack from Rome and Berlin. Even so no misrepresentation is necessary or permissible.

\section{CONCLUSIONS}

In sum, it may be suggested that no simple conclusion would fit the complex situation just studied, that the elements chiefly determining the results, intermediate and ultimate (down to date), lie in the political conditions in the Member States and the international community, while a certain responsibility for the outcome must be charged to Secretariat officials, the theories which they feel compelled to adopt, and the practices carried out under them. That different results could have been obtained by different methods is possible but not certain. 